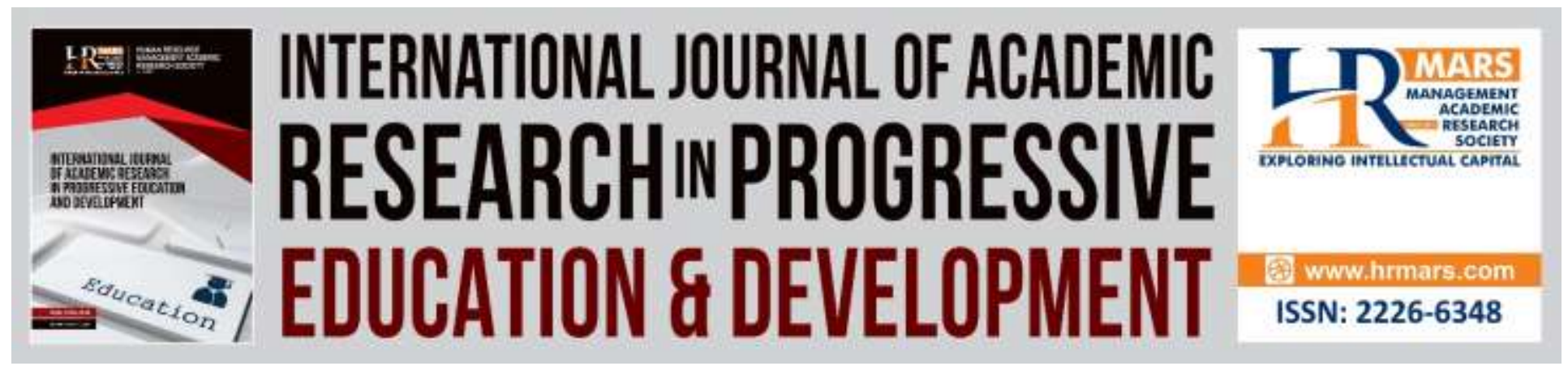

\title{
Exploring the Factors Affecting the Gap on Literacy Skills among Students with Learning Disabilities: A Case Study
}

Nur Farhana Mohamed Zaki, Nor Aniza Ahmad, Muhammad 'Ilman Mohamed
'Ashri

To Link this Article: http://dx.doi.org/10.6007/IJARPED/v8-i3/6389

DOI: $10.6007 /$ IJARPED/v8-i3/6389

Received: 11 July 2019, Revised: 19 August 2019, Accepted: 02 September 2019

Published Online: 23 September, 2019

In-Text Citation: (Zaki, Ahmad, \& 'Ashri, 2019)

To Cite this Article: Zaki, N. F. M., Ahmad, N. A., \& 'Ashri, M. 'Ilman M. (2019). Exploring the Factors Affecting the Gap on Literacy Skills among Students with Learning Disabilities: A Case Study. International Journal of Academic Research in Progressive Education and Development, 8(3), 237-247.

Copyright: (c) 2019 The Author(s)

Published by Human Resource Management Academic Research Society (www.hrmars.com)

This article is published under the Creative Commons Attribution (CC BY 4.0) license. Anyone may reproduce, distribute, translate and create derivative works of this article (for both commercial and non-commercial purposes), subject to full attribution to the original publication and authors. The full terms of this license may be seen

at: $\underline{\text { http://creativecommons.org/licences/by/4.0/legalcode }}$

Vol. 8(3) 2019, Pg. 237 - 247

http://hrmars.com/index.php/pages/detail/IJARPED

JOURNAL HOMEPAGE

Full Terms \& Conditions of access and use can be found at http://hrmars.com/index.php/pages/detail/publication-ethics 


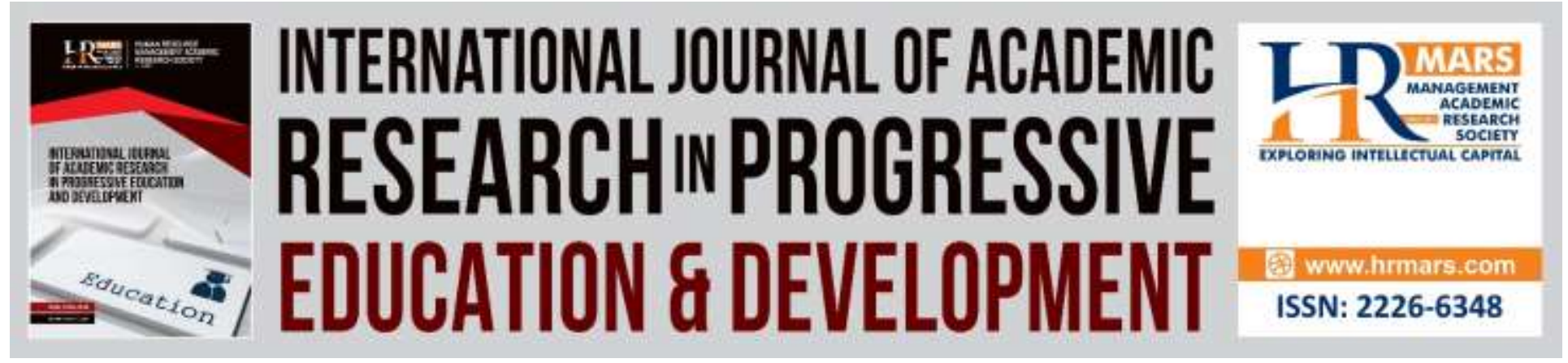

\title{
Exploring the Factors Affecting the Gap on Literacy Skills among Students with Learning Disabilities: A Case Study
}

\author{
Nur Farhana Mohamed Zaki, Nor Aniza Ahmad (PhD), \\ Muhammad 'Ilman Mohamed 'Ashri \\ Faculty of Educational Studies, Universiti Putra Malaysia \\ Email:nor_aniza@upm.edu.my
}

\begin{abstract}
The wide gap in literacy proficiency among students with learning disabilities is one of the rising issues in education field. This study is conducted to find out the factors that contribute towards the gap on literacy skills among students with learning disabilities and mainstream students. Furthermore, teachers' strategy to improve the literacy skills among learning disabilities students also inquired. Besides, this study also discussed about the interventions or programs that have been implemented to help these students. An interview with three special needs teachers at Sekolah Kebangsaan Putrajaya Presint 16(2) is conducted to investigate this issue. The findings shows that lack of awareness among parents which then causing their children to received late interventions is among the causes for unsatisfactory literacy skills. It is important for teachers to use variety of teaching strategies to reduce the gap on literacy skills. At the end of this paper, the author discussed on how to enhance the intervention programs and what teachers and parents role to fit the needs of these students. The findings of this study provide new dimension in explaining the importance in reducing the gap on literacy skills among special education needs students.

Keyword: Literacy Skills, Literacy Gap, Learning Disabilities, Teaching Strategies, Intervention Programs

\section{Introduction}

In special needs education, there are many types of children with different needs to be fulfill. Learning disabilities children are one of them. Learning disabilities is a term that describes several types of developmental disorders such as difficulties in learning specific academic or language skills, including reading, mathematics, speech, writing, and motor performance (American Psychiatric Association, 2013). Children with learning disabilities also have difficulty to learn particular skills or specific academic subjects. However, learning disabilities are not related to
\end{abstract}


intelligence. They are often physiological, as in the brain of someone with learning disabilities; it may be wired differently than other people's brains.

Meanwhile, Keefe and Copeland (2011) had proposed five core principles of definition for literacy. One of it is that literacy involves interaction, contact, and expecting all people to be able to communicate while also has the ability to lead to empowerment. Furthermore, literacy also includes continuity for learning which enables the person to accomplish their objectives, improve their understanding and capability, and actively engage in their society and the world (UNESCO, 2004; 2017). Besides, literacy also can be described as the ability to use language and images in rich and varied forms to read, write, listen, speak, view, represent, discuss and think critically about ideas (Ministry of Education Ontario, 2013). Reading and writing skills is a part of literacy skills which the foundation for effective teaching and learning process in various types of disciplinary (Jamian, 2011).

As children get older and continue to lag further behind their friends, it becomes more difficult for them to obtain productive intellectual and social-emotional results (Dovey, 2018). So, it is important to identify these learning disabilities children and provide them with earliest intervention so that they would be able to live a successful life as others. Besides that, most of the children that had been diagnosed with learning disabilities are not less in intelligence, it just that their potential were hidden and required assistive resources in order for them to live successful life as others.

In this study, the author wanted to explore on the factors affecting the gap on literacy skills among mainstream students and learning disabilities students at Special Education Integrated Program. This study intends to find out the teachers' perspectives on the factors that may cause this outcome. Besides, these teachers also had been inquired on their strategy, standardized activities or programs as well as the interventions held for these students.

\section{Significance of the Study}

Literacy skills which include reading and writing are one of the important skills that every child needs in order to help them learn progressively as well as their peers. Literacy skills also help a person to participate independently and contribute significantly in a community, and also increase chances for employment (Spooner et al., 2015). That is why it is important to do research on how to improve their literacy skills and close the gap between normal students and learning disabilities students.

By understanding the factors influencing the gap on literacy skills, it may help to increase awareness to the community and reduced the children at risk to have difficulties in learning literacy. Besides, through this research, the researchers would like to find out the possible efforts that can be done by educators and community in order to increase literacy proficiency among these students. Therefore, the main purpose of conducting this study is to explore the affecting factors for the huge gap on literacy skills among learning disabilities students and mainstream students. 
INTERNATIONAL JOURNAL OF ACADEMIC RESEARCH IN PROGRESSIVE EDUCATION AND DEVELOPMENT

Vol. 8, No. 3, 2019, E-ISSN: 2226-6348 ㄷ 2019 HRMARS

\section{Objectives}

The objectives for this study are:

1. To find out the factors that affect the gap on literacy skills among students with Learning Disabilities with mainstream students

2. To find out the strategies or activities used by teachers to improve literacy skills among students with Learning Disabilities.

3. To find out the suitable intervention programs or therapies for students with Learning Disabilities.

\section{Literature Review}

Most of the previous research had focused on one aspect of learning disabilities such as reading disability or cognitive factors of the disability (Moll et al., 2016; Tummer \& Hoover, 2017; Shankweiler et al.,2017). In addition, some of the parent or even educators thought that learning disabilities is only children with brain dysfunction such as syndrome down whereby there is actually a few more other than that such as autism, ADHD, dyslexia and cerebral palsy. So, the author intends to figure out more on the other factors that may lead to learning disabilities besides chromosome abnormality among these children.

A research had stated that there are many children with learning disabilities that have low literacy skills, especially in reading. It is found that reading performance for students with learning disabilities at the secondary school level is on average 3-4 years behind their admitted grade level (Mooney \& Silver-Pacuilla, 2010). On another literature, the difficulties in developing literacy skills experienced by many students with intellectual impairments, multiple impairments, and autism are can be associated with specific cognitive deficits and impaired underlying processes (Foley, 1993).

Meanwhile, some studies proposed that skills in literacy might be affected by selfconfidence and intrinsic motivation (Lacono et al., 2001; Ross et al., 2016). A major reason of these students' lack of literacy abilities may be that they have inadequate comprehension for learning tasks that they are requested to undertake and therefore have restricted interest in fulfilling the reading and writing assignments. Moreover, when being taught with literacy skills, students with learning disabilities need to be involved in learning experiences that make sense to them (Basil \& Reyes, 2003).

On the other hand, one of the main cause for difficulty in developing literacy skills among these students is because of the cognitive impairments (Moll et. al, 2014; Peterson et al., 2016; Bathelt et al., 2017). These studies suggested that reading disabilities among children are highly affected by processing speed and verbal memory. The impairment for this function in the brain could possibly be the main factor for slow development of literacy skills among the children.

A few researches stressed on the importance of early detection for learning disorders among children of early age (Peterson et al., 2016). It may help them receive proper early interventions which may provide a strong foundation for literacy learning process.

Besides, there are many interventions had been introduced over the years in order to improve literacy skills among learning disabilities student. It has been reported that reading skills are significantly related with phonological skills. So, it has been proposed that by resolving 
children verbal difficulties and phonological before they start learning literacy, they may prevent literacy difficulties among young children (Nathan et al., 2004). Another research has supported the usage of e-book as a tool for literacy learning in order to enhance literacy development among these students (Shamir et al., 2012).

\section{Methodology}

This study is a qualitative research by doing a case study. Interview method was implemented in this study while the respondents were teachers from special needs education backgrounds. Three teachers from Sekolah Kebangsaan Putrajaya Presint 16(2) had volunteered to be interviewed. This school was chosen as location of the study because there is a Special Education Integrated Program.

Before conducting the interview, the school had been informed through email about the study. A briefing was given to the schools and teachers about the purpose and process of the study. Then, as the school had given the permission to conduct this study, three teachers volunteered to participate as respondents. In this school, this program focuses on providing education for learning disabilities students. There are diverse backgrounds of students who have learning disabilities including autism, syndrome down, cerebral palsy, ADHD, speech disabilities, dyslexia and a few others. Compare to other students in mainstream education, in this special education integrated program, they use special needs syllabus that are much easier than KSSR.

Meanwhile, the instrument used in this study was a set of interview questions that had been constructed by the researcher to achieve the objectives of this study. Among the main questions that are being asked is about the teachers' perspectives on the factors that contribute toward the gap on literacy skills between the mainstream students and students with learning difficulties. Besides that, the researcher also asked about the strategies or activities that teachers had introduced to improve students' literacy skills and reduce the gap; as well as a few questions about the intervention programs that being organized to help these learning disabilities students.

\section{Findings and Discussion}

There is such a huge gap of literacy skills among learning disabilities students with mainstream students. Furthermore, in the same class, there are also huge differences among the disabilities students on the literacy skills. There are students who are able to read and students who do not know the slightest about alphabet in the same class.

\section{Factors that Affect the Gap on Literacy Skills}

During this study, it is found that there are a few factors that may influence student's literacy skills. Firstly, physical or physiological disabilities are one of the main causes for the low literacy skills among these students. For instance, cerebral palsy students who had difficulties to learn to write because of lack of motor skills. One of the respondent said her opinion where she said, "I think that their motor, especially fine motor skills, may be the factor for difficulties in learning literacy. One of cerebral palsy students here has problem with his hands. So, it had affected him a lot on his abilities to write." This is supported by a research that children with motor skills impairment would highly develop reading and writing difficulties (O'Hare \& Khalid, 2002). It is also the same issue for students with intellectual disabilities such as syndrome down children. 
Because of their condition where they are born with these conditions which cannot be easily cure or treated, they are having slower progress in learning things including developing literacy skills.

Besides that, another major factor for literacy problems among students with learning disabilities is that they are not being introduced with learning routine from early age where they often overlook the significance of learning how to write or read. Parents who do not introduce learning purpose and routine from early age will cause the lack of readiness and motivation to learn as they see it as not important or needed. They will still immersed in playing and have no drive to learn. Some parents believe that children would be able to catch up to learn basic literacy skills when they enter elementary schools. However, without readiness to learn from the children, it causes the learning process to be much difficult and challenging. Past researches had suggested that pre-literacy knowledge would be one of the predictors towards these children later performance in literacy skills (Pentimonti et al., 2016). So, by introducing learning routine such as alphabet or phonics in a fun way during young age, they will be accustomed with learning environment. There are a student that had been added to inclusive program in mainstream education program and perform well in academic because of the parents had been sending him for tuition class and nurture learning routine from young age.

Besides lack of readiness, lack of intrinsic motivation is one of the risk factor for a child to develop learning disabilities. Students that are not used to read or write during young age would not be motivated to do so when they enter the school. They would feel that it is already late for them to learn to do so as they are much behind than their peers. Most of the students who are struggling in doing some tasks would eventually lost interest and motivation to do so. For example, students who find it hard to read would hardly like to read even they know the importance of reading. (Melekoğlu \& Wilkerson, 2012). The respondents in this study said that it is hard to maintain students' interest in learning literacy as they have no motivation to do that. That is why sometimes they had to be creative by incorporate literacy lesson in a fun way.

In addition, parents that fail to identify their children late development may also fails to provide early intervention programs or therapies to these children. This is because most of the time, parents had ignore the possibilities of their children having the disabilities and just assume that they are just naughty or lazy to learn. Only after they had been going to school and facing problems to learn properly, the child was identified to be having these disabilities. At that time, it surely will be harder for the child to adapt with learning environment as he or she had not been exposed to it much earlier. If earlier intervention had been given to the child, he or she will be more ready and able to adapt easier with new learning environment. Besides, some children that just had difficulties with psychomotor coordination, might be able to learn literacy skills such as writing and reading better if they were exposed to occupational therapies from early age. This is supported by a research which had suggested that in order to close the gap between students with language disabilities and typical students in reading abilities, it is important for these students to receive proper language and literacy instruction from earliest age possible (Skibbe et al., 2008).

\section{Strategies and Activities to Improve Literacy Skills}

Throughout this study, it is found that even in the same class, there is a huge gap in students' literacy skills among the students. It is because in this special education integrated program, they 
focus more on mastery learning. The students have to understand the basic skill first for them to proceed to another level of the lesson. So, the student who takes more time in mastering certain skills or knowledge would be much behind in literacy performance compare to the others.

So, in order to improve their readiness and focus, teachers have to identify their interest and favourite things to make use of it as rewards or attention grabber. For example, at the beginning of the class, teacher would attract their attention and increase their mood by through songs, attractive sounds such as animal sounds or videos of their favourite characters. Then, after they grab their attention, teachers can start the lessons. Sometimes, these videos can be used as reward for them if they done a good job during learning session.

As they are only able to focus for a short period of time and always love to play, it is also important to integrate important lesson through playing. Teachers have to be creative and flexible and know how to manipulate students' moods. Play therapy also served as one of the lesson for these students. Just by playing with Lego's bricks or doing star jumping, they are able to improve their fine and gross motor skills. So, by integrate playing during the lesson, they would be able to focus more in class and also enjoy the learning process.

One of the teachers said "For the students that have potential to read, I held extra class after school session has finished. I will take around 30 minutes to guide them on how to read using a book named KALAM". So, as being said by the respondent, in order to boost students' potential, some teachers willing invest some time to give extra lesson after the schools ends by using other reliable books or interactive teaching aid as different approach to learning process. One of the books that had been used to improve reading skills is "KALAM" book.

For examples, the usage of laptop and television had been widely used as teaching aids. Students are often given screen time as rewards or reinforcement. Of course, interactive and informative videos and movies are showed so that even for entertainment, they will also absorb beneficial input from the shows. Besides, technologies also being used to improve their literacy skills as the uses of latest gadget boost students' moods and interest to learn. In addition, it is found that visual presentation of the lesson could improve student engagement in literacy learning (Parsons et al., 2015). However, there are always insufficient devices for all students because of financial constraint. Some teachers would buy online teaching aids to help them in teaching.

\section{Intervention Programs and Therapies}

There are a few intervention programs that can be conducted in order to help students in improving their literacy skills. One of the interventions is by collaborating with mainstream students programs. Program such as awareness campaign, language week or entrepreneur week can be organized and includes all students. From the inclusive programs like this, learning disabilities students are given opportunities to associate with other people and learn together with them. Social interactions with peers of the same ages may boost their interest to learn.

Besides, teachers also try to introduce these students with real-life experiences such as shopping and buying things. Instead of just doing simulations in class, they would attempt to do simple task by themselves which help them to understand things better. They get to meet different kinds of people and associate with them. As they get more familiar around people, they will adapt better in learning new things from others. 
In order to assist learning process, teachers also incorporate therapy steps during learning session in order to increase their focus span. Higher focus in class will directly contribute towards more effective learning process. In order to aid learning process, teachers applies therapies approach into the classroom setting. In order to do that, teachers have to do more research or collaborate or trained with professional therapist to learn the right steps to do it.

In addition, there are also other therapies that usually being held outside of school setting such as horse riding, archery, swimming and bowling. These sports plays major role in building self-confidence, enhance focus, and improve motor coordination among these special needs students. One of the respondents said that, "Archery is good for focus, while horse riding and swimming are good for building up confidence.

\section{Conclusion}

From this study, the author find out that a child readiness for learning is one of the main factors that influence the development of literacy skills. If a child with learning disabilities had been introduced with early intervention and the purpose of learning using appropriate learning resources before they start formal education, they had higher chance to develop literacy skills as progressively as mainstream students.

In addition, the literacy skills among learning disabilities students indeed have a huge gap compared to mainstream students. However, there are always alternatives and opportunities for them to improve to the same level as their peers. From this study, it is found that there are a few students that had been transferred to mainstream classroom and showing achievement in academic. It shows that learning disabilities students are able to perform well in academic as well as literacy development as mainstream students. The teacher said that his parents support him well by providing him with tuition after class as well as he had received intervention to help his academic development from very young age.

So, the author concludes by emphasizing on early intervention programs and therapies, it increases the possibilities for them to develop basic literacy skills as well as increasing their opportunity to have a better future. Besides that, it is also important for them to receive support from their parents. Parents are the person that are closest to the students and spend more time with them. So, parents have to be more supportive in terms of emotional, psychological and also financial in order to help their children be the best version of them.

\section{Implications and Recommendation}

In this study, a few possible factors for learning disabilities among children had been identified. In order to prevent learning difficulties to worsen in the future, and further widen the literacy gap among learning disabilities students and mainstream students, the author had propose a few suggestions.

In order to improve special needs education in providing proper education to students with learning disabilities, more complete facilities should be added to aid teaching process and providing conducive learning environment to the students. Laptop and tablet should be provided as it is one of the most important teaching aids. Besides, for learning disabilities students, Visual Reality (VR) room and Sensory Integration (SI) room are important facilities to boost students 
learning experiences. So, these kinds of rooms should be provided in special needs education centre.

There are schools or special needs educations centre that have a complete facilities but did not being fully utilized by the students. In order to maximize the usage of these facilities, they should invite or organised programs or therapies for special needs students from other schools or centre. These kind of collaboration will give every side involves win-win situation.

Other aspects of providing better education to these students, it is also important to hold more training focusing on new and latest strategies and techniques of instruction for special education teachers. They should be trained properly to handle therapy session or at least integrate therapy methodology in classroom. Furthermore, more seminars or campaign should be held to increase parents and community involvement in special education programs.

On the other hand, the author would like to suggest for educators and researchers to do future researches on the awareness among parents on understanding if their children are at risk of having learning disabilities. It is also important to do research on how many parents with learning disabilities children send their children for intervention and therapies as early as possible to prepare them for learning environment. If parents had introduced the child with intervention and therapies at very young age, it will increase the students' readiness and focus much earlier with will be a great help when they start going to schools. Besides, home is always the first place of education for children. So it is important for parents to have awareness on their child learning development as they have to prepare their child to be ready to learn. If they are late in their growth, be it physical growth or intellectual, parents have to consult with professional expert in order to help their children as soon as possible.

Moreover, more researches on the influence of literacy skills on the self-development and social adaptation of students with learning disabilities should be conducted. It is because literacy skills also contribute towards communication skills and how a person interact with others. So, with more researches on learning disabilities aspects, it is hoped that special needs education may progressively improve in the future.

\section{Acknowledgement}

The authors are thankful to Universiti Putra Malaysia for giving the opportunity to publish this article and all the personnel involves in this study.

\section{Corresponding Author}

Dr. Nor Aniza Ahmad

Department of Foundations of Education, Faculty of Educational Studies, Universiti Putra Malaysia, 43400 UPM Serdang, Selangor, Malaysia.

Email:nor_aniza@upm.edu.my

\section{References}

American Psychiatric Association. (2013). Diagnostic and statistical manual of mental disorders. BMC Med, 17, 133-137.

Basil, C., \& Reyes, S. (2003). Acquisition of literacy skills by children with severe disability. Child Language Teaching and Therapy, 19(1), 27-48. 
INTERNATIONAL JOURNAL OF ACADEMIC RESEARCH IN PROGRESSIVE EDUCATION AND DEVELOPMENT

Vol. 8, No. 3, 2019, E-ISSN: 2226-6348 @ 2019 HRMARS

https://doi.org/10.1191/0265659003ct242oa

Bathelt, J., Gathercole, S. E., Butterfield, S., \& Astle, D. E. (2017). The role of the structural connectome in literacy and numeracy development in children. https://doi.org/10.31234/osf.io/jk6yb

Dovey, C. (2018). The Signal: Closing the gaps for students with learning disabilities. Retrieved September 17, 2019, from https://www.edcan.ca/articles/signalincreased-focus-closing-gaps-students-learning-disabilities/

Frankenburg, W. K., Dodds, J., Archer, P., Shapiro, H., \& Bresnick, B. (1992). The Denver II: a major revision and restandardization of the Denver Developmental Screening Test. Pediatrics, 89(1), 91-97.

Frankenburg, W. K., \& Dodds, J. B. (1967). The Denver developmental screening test. The Journal of pediatrics, 71(2), 181-191.

Foley, B. E. (1993). The Development of Literacy in Individuals with Severe Congenital Speech and Motor Impairments. Topics in Language Disorders, 13(2), 16-32.

lacono, T., Balandin, S., \& Cupples, L. (2001). Focus group discussions of literacy assessment and world wide web-based reading intervention. Augmentative and Alternative Communication, 17(1), 27-36. https://doi.org/10.1016/j.lisr.2016.01.002

Jamian, A. R. (2016). Permasalahan kemahiran membaca dan menulis Bahasa Melayu muridmurid sekolah rendah di luar bandar. Jurnal Pendidikan Bahasa Melayu, 1(1), 1-12.

Liyana, A. A., Nurul, F. H., \& Khuzaiton, Z. (2013). Persepsi dan pengalaman guru pendidikan khas dalam menghadapi permasalahan disleksia dalam kemahiran literasi. In Seminar Sains Kemanusiaan OKU Peringkat Kebangsaan (pp. 1-14).

Melekoglu, M. A., \& Wilkerson, K. L. (2012). Motivation to Read: How Does It Change for Struggling Readers with and without Disabilities? International Journal of Instruction, 6(1). Retrieved from https://dergipark.org.tr/tr/pub/eiji/issue/5138/70017

Ministry of Education Ontario. (2013). Paying Attention to Literacy K-12. Retrieved from http://www.edu.gov.on.ca/eng/literacynumeracy/paying_attention_literacy.pdf

Moll, K., Gobel, S. M., Gooch, D., Landerl, K., \& Snowling, M. J. (2016). Cognitive risk factors for specific learning disorder: Processing speed, temporal processing, and working memory. Journal of learning disabilities, 49(3), 272-281.

https://doi.org/10.1177/0022219414547221

Mooney, M., \& Silver-Pacuilla, H. (2010). Literacy, Employment and Youth with Learning Disabilities: Aligning Workforce Development Policies and Programs. National Institute for Literacy.

Nathan, L., Stackhouse, J., Goulandris, N., \& Snowling, M. J. (2004). The development of early literacy skills among children with speech difficulties. Journal of Speech, Language, and Hearing Research. 47(2), 377-391. https://doi.org/10.1044/1092- 4388(2004/031)

O'Hare, A., \& Khalid, S. (2002). The association of abnormal cerebellar function in children with developmental coordination disorder and reading difficulties. Dyslexia, $8(4)$, 234-248. https://doi.org/10.1002/dys.230

Parsons, S. A., Malloy, J. A., Parsons, A. W., \& Burrowbridge, S. C. (2015). Students' engagement in literacy tasks. The Reading Teacher,69(2), 223-231. https://doi.org/10.1002/trtr.1378 
Pentimonti, J. M., Murphy, K. A., Justice, L. M., Logan, J. A., \& Kaderavek, J. N. (2016). School readiness of children with language impairment: predicting literacy skills from pre-

literacy and social-behavioural dimensions. International Journal of Language \& Communication Disorders, 51(2), 148-161. https://doi.org/10.1111/1460-6984.12193

Peterson, R. L., Boada, R., McGrath, L. M., Willcutt, E. G., Olson, R. K., \& Pennington, B. F. (2017). Cognitive prediction of reading, math, and attention: Shared and unique influences. Journal of learning disabilities, 50(4), 408-421. https://doi.org/10.1177/0022219415618500

Ross, M., Perkins, H., \& Bodey, K. (2016). Academic motivation and information literacy selfefficacy: The importance of a simple desire to know. Library \& information science research, 38(1), 2-9. https://doi.org/10.1016/j.lisr.2016.01.002

Shankweiler, D., Crain, S., Brady, S., \& Macaruso, P. (2017). Identifying the causes of reading disability. In Reading acquisition (pp. 275-305). Routledge.

Shamir, A., Korat, O., \& Fellah, R. (2012). Promoting vocabulary, phonological awareness and concept about print among children at risk for learning disability: can e-books help?. Reading and Writing, 25(1), 45-69. https://doi.org/10.1007/s11145-010-9247$x$

Skibbe, L. E., Grimm, K. J., Stanton-Chapman, T. L., Justice, L. M., Pence, K. L., \& Bowles, R. P. (2008). Reading trajectories of children with language difficulties from preschool through fifth grade. Language, speech, and hearing services in schools. https://doi.org/10.1044/0161-1461(2008/07-0016)

Spooner, F., Kemp-Inman, A., Ahlgrim-Delzell, L., Wood, L., \& Davis, L. (2015). Generalization of literacy skills through portable technology for students with severe disabilities. Research and practice for persons with severe disabilities, 40(1), 52-70. https://doi.org/10.1177/1540796915586190

Tunmer, W. E., \& Hoover, W. A. (2017). Cognitive and linguistic factors in learning to read. In Reading acquisition (pp. 175-214). Routledge.

UNESCO. (2004). The plurality of literacy and its implications for policies and programmes. Unesco.

UNESCO. (2017). Reading the past, writing the future: Fifty years of promoting Literacy. 